\title{
Effect of Cobalt Application and Mycorrhizal Fungi Inoculation on Growth and Some Nutrients Content of Barley and Egyptian Clover Plants Grown in Calcareous Soil
}

\author{
Meftah $^{1}$, M.A., I.I. Abou El-Seoud ${ }^{2}$., M. G. Nassem ${ }^{2}$ and M. Abou El-Maged ${ }^{2}$ \\ ${ }^{1}$ Department of Soil and Water, Faculty of Agriculture, University of Bani walid-Libya. \\ ${ }^{2}$ Department of Soil and Agricultural Chemistry, Faculty of Agriculture, Saba Bash, \\ Alexandria University Egypt
}

Corresponding author: M. Meftah, e-mail: M Meftah@hotmail.com

\begin{abstract}
Two pot experiments were carried out at the green-house of Faculty of agriculture (Saba Bash), Alexandria University to study the effect of cobalt applied with seeds through soaking in relation to mycorrhiza inoculation on growth and quality of barely and clover as forage crops under calcareous soil conditions during 2012-2013 and 2013-2014 growing seasons, respectively. The seeds of barley and clover were soaked in continuously aerated solution of different cobalt concentrations $(0.0,0.3,0.6,0.9,1.2$, and $1.5 \mathrm{mg} / \mathrm{l})$ using cobalt sulphate salt and inoculated with two mycorrhizal spices ( $G$. intraradiaces and $G$. macrocarpium) separately before sowing.The obtained results showed that soaking seeds of barley and clover (forage crops) in cobalt solutions and mycorrhizal inoculation had significant effects on all growth parameters and the tested nutrients content in the plants of the two crops. The Co significantly increased the contents of $\mathrm{N}, \mathrm{P}, \mathrm{K}$, and $\mathrm{Co}$ in shoot and root of the tested plants. It was found that G. intraradiaces was more effective than G. macrocarpium for the studied traits. Also, the recommended cobalt concentration for barley crops was lower $(0.6 \mathrm{mg} / \mathrm{l})$ than that for E.Clover $(1.2 \mathrm{mg} / \mathrm{l})$. However, Co concentration above 0.6 and $1.2 \mathrm{mg} / \mathrm{l}$ for barley and E. Clove, respectively, reduced growth of plants.
\end{abstract}

Key wards: Seeds soaking, cobalt, Mycorrhiza, Barley, E. Clover, growth parameters, macronutrients.

\section{INTRODUCTION}

Barley (Hordeum vugare_L.) is the major cereal crops in many dry areas of the Middle East, North Africa and west Asia (Ceccerelli et al., 1987). Its distribution is worldwide and is of considerable economic importance for animal feed and human consumption. Throughout the world around, $80 \%$ of the grown barley is used to feed animals (Amri et al. 2005).

Berseem or Egyptian clover (Trifolium alexandrinum L.) is an annual legume that is a vine with climbing growth habit, great productivity due to its high growth rate and good fodder recovery after cutting, and high levels of crude protein. It is well adapted to a range of environments and is usually grown in the Mediterranean, central European, and Southeast Asian Countries for forage production (El-Bably, 2002; De Santis et al., 2004).

Cobalt is required by Rhizobia for nitrogen fixation and indirectly by leguminous and other plants (Riley and Dillwarth, 1985). On the other hand, low concentrations of cobalt can have a favorable effect on plant growth of nonleguminous crops (Walser et al., 1996). Cobalt affects metabolism and plant 
growth and is an essential component of several enzymes and co-enzymes (Palit et al., 1994). Its beneficial effects include retardation of leaf senescence, inhibition of ethylene biosynthesis, and stimulation of alkaloid biosynthesis (Palit et al., 1994).

There are three main methods of adding micronutrients to crops: soil fertilization، foliar sprays and seed treatment. Atta-Aly (1998) found that soaking summer squash (Cucurbita pepo cv. Esksandarany) seed in continuously aerated solution of $0.25,0.50$, and $1.00 \mathrm{ppm} \mathrm{Co}^{2+}$ for $48 \mathrm{~h}$ before sowing strongly increased plant growth, femaleness, and fruit yield compared with those of water(control) or $0.5 \mathrm{mM}$ amino Oxyacetic acid soaked seed. In the same line, Atta-Aly (2003) reported that soaking Galia melon (Cucumis melo var. reticulatus, c.v. Royal) seed in continuously aerated solution of $1.00 \mathrm{ppm} \mathrm{Co}^{2+}$ for $48 \mathrm{~h}$ before sowing significantly increased ethylene $\left(\mathrm{C}_{2} \mathrm{H}_{4}\right)$ level, plant growth and fruit yield compared with those of water- soaked seeds.

Arbuscular mycorrhizal fungi (AMF) play an important role in vegetation restoration because of symbiosis with plant root; they can facilitate mineral absorption by host plant, stability and improve soil structure, affect the population structure and preserve species diversity (Bothe et al., 2010).

Gad et al., (2012) studied the effect of cobalt and mycorrhizae (Gigaspora gigantean) on growth and yield of corn as monocots and soybean as dicots. The seedling (at the third truly leaf) were irrigated with cobalt sulphate once, with 0,4 , 8, 10, 12, 16 and 20 ppm cobalt. They found that the cobalt with mycorrhizae inoculation under low phosphorus level enhanced the growth, yield quantity and quality in both corn and soybean, but this positive impact was more significant in the dicot plants compared to monocot.The aim of this research was to study the effect of cobalt application using soaking seed method and mycorrhizal fungi inoculation on growth and nutrients content of barley (non-legumes) and Egyptian Clover (legumes) grown on calcareous soil.

\section{MATERIALS AND METHODS}

\section{Soil}

Surface calcareous soil sample $(0-15 \mathrm{~cm})$ was collected from Al-Hamam region at the northern western coast of Egypt. The soil sample was air dried ground to pass $2 \mathrm{~mm}$ sieve and thoroughly mixed before using. The characteristics of this soil are presented in Table (1). Practical size distribution was determined by the hydrometer method according to Black (1965). Field capacity was measured by saturated the soil samples through capillary rise then pull the gravitational water from the samples and drying at $105^{\circ} \mathrm{C}$ for 24 hours as reported by Black et al. (1965). Soil organic matter was determined by Walkley and Black method according to Jackson (1973). The water soluble $\mathrm{Ca}^{2+}, \mathrm{Mg}^{2+}, \mathrm{HCO}_{3}^{-}, \mathrm{Cl}^{-}, \mathrm{pH}$ and EC in the soil were measured according to Jackson (1967). The calcimeter method was used to determine the total carbonates volumetrically (Black, 1965). The 
J. Adv. Agric. Res. (Fac. Agric. Saba Basha)

amounts of available nitrogen and potassium were determined according to Jackson (1967), that of phosphorus was determined as described by Murphy and Riley (1962), and that of cobalt was determined using the methods of Lindsay and Norvell (1978).

Table (1). The main physical and chemical properties of the experimental soil

\begin{tabular}{|c|c|c|c|c|c|c|c|c|}
\hline Soil property & \multicolumn{4}{|c|}{ Particle size distribution } & \multirow{2}{*}{\multicolumn{4}{|c|}{$\begin{array}{c}\text { Soil moisture content } \\
\text { F.C } \%(w: w)\end{array}$}} \\
\hline \multirow{2}{*}{ Physical } & Sand \% & Silt\% & Clay\% & Texture & & & & \\
\hline & 73 & 14 & 13 & Silty loam & \multicolumn{4}{|c|}{20} \\
\hline \multirow{5}{*}{ Chemical } & \multicolumn{2}{|c|}{$\begin{array}{c}\mathrm{pH}(1: 1) \\
8.0\end{array}$} & \multicolumn{2}{|c|}{$\begin{array}{c}\mathrm{EC}\left(\mathrm{dSm}^{-1}\right)(1: 1) \\
2.14\end{array}$} & \multicolumn{2}{|c|}{$\begin{array}{c}\mathrm{CaCO}_{3} \% \\
19.95\end{array}$} & \multicolumn{2}{|c|}{$\begin{array}{c}\text { O.M (\%) } \\
1.06\end{array}$} \\
\hline & \multicolumn{4}{|c|}{ Water soluble cation (meq/l) } & \multicolumn{4}{|c|}{ Water soluble anion (meq/l) } \\
\hline & $\begin{array}{l}\mathrm{Ca}^{2+} \\
7.0\end{array}$ & $\begin{array}{c}\mathbf{M g}^{2+} \\
2.5\end{array}$ & $\begin{array}{l}\mathbf{K}^{+} \\
0.87\end{array}$ & $\begin{array}{l}\mathrm{Na}^{+} \\
13.1\end{array}$ & $\begin{array}{l}\mathrm{HCO}_{3}^{-} \\
4.00\end{array}$ & $\mathrm{CO}_{3}^{-}$ & $\begin{array}{l}\mathrm{SO}_{4}{ }^{2-} \\
5.08\end{array}$ & $\begin{array}{c}\mathrm{Cl}^{-} \\
14.00\end{array}$ \\
\hline & \multicolumn{8}{|c|}{ Available nutrients (mg/kg soil) } \\
\hline & $\begin{array}{l}\mathbf{N} \\
60\end{array}$ & & $\begin{array}{l}\mathbf{P} \\
7\end{array}$ & $\begin{array}{c}\mathbf{K} \\
185\end{array}$ & & & $\begin{array}{l}\text {-Co } \\
96\end{array}$ & \\
\hline
\end{tabular}

\section{Seed soaking in cobalt solutions}

The seeds of barley or clover were soaked for $48 \mathrm{~h}$ at room temperature in continuously aerated solutions of 0.00 (distilled water), $0.3,0.6 .0 .9,1.2$ and 1.5 $\mathrm{mg} \mathrm{L}^{-1} \mathrm{Co}^{2+}$ using cobalt sulphate salts as described by Atta-Aly (1998). By the end of soaking, the seeds were radicated with a ridacle length of $1-1.5 \mathrm{~mm}$ and were directly sown.

\section{Experimental procedures}

Two pot experiments were carried out at the green-house of Faculty of agriculture (Saba Basha), Alexandria University to study the effect of cobalt applied with seeds through soaking in relation to mycorrhiza inoculation (Glomus macrocarpium (G.M) or Glomus intraradiaces (G.I)) on the growth and quality of barely crop (Hordeum vulgare,L.) during 2012-2013 growing season and on Egyptian Clover (Trifolum alexandarinum,L.) during 2013-2014 growing season under calcareous soil conditions. Plastic pots $(12.5 \mathrm{~cm}$ diameter and $11.5 \mathrm{~cm}$ depth) were filled with $1 \mathrm{~kg}$ calcareous soil for each pot. The barley and E. Clover were fertilized by recommended dose of super phosphate $\left(15 \% \mathrm{P}_{2} \mathrm{O}_{5}\right)$, which was added and mixed with soil in each pot during the preparation of the experimental soil at the rate of (90 and $200 \mathrm{~kg} \mathrm{P}_{2} \mathrm{O}_{5} / \mathrm{fed}$ ) respectively, while $\mathrm{N}$ fertilizer was added in the form of $\left(\mathrm{NH}_{4} \mathrm{NO}_{3}, 33 \% \mathrm{~N}\right)$ at the rate of (100 and $50 \mathrm{~kg} \mathrm{~N} / \mathrm{fed}$ ) in three equal dose, and $\mathrm{K}$ fertilizer was added in the form of $\mathrm{K}_{2} \mathrm{SO}_{4}\left(\mathrm{~K}_{2} \mathrm{O} 50 \%\right)$, at the rate of (50 and $100 \mathrm{~kg} / \mathrm{fed}$ ) for barley and clover, respectively. Five grams of mycorrhiza (about 500 spores) inoculate (mycorrhiza spores with sand) was applied in a hole under the seeds before planting. Ten seeds bed of barely or clover were sown in each pot in holes and the seedlings were thinned to six plants per pot after three weeks from sowing. The seeds of Egyptian clover (Balady 1) were inoculated prior sowing with the specific strain of rhizobium leguminosarum. Soil moisture content 
was monitored at $80 \%$ of field capacity daily by distilled water. The cobalt (the main plot) and arbuscular-mycorrhizal (AM) species (the sub plot) treatments for the experiment were distributed in complete randomized block design with three replicates. At the harvest time (50, 47 days after planting of barley and clover, respectively), the plant height and number of leaves were measured. Also, samples of soil were collected from each pot and available cobalt was determined (Lindsay and Norvell, 1978).

\section{Morphological root parameters}

Plant roots were removed from each pot and separated from soil by washing under a jet of tap water on a $0.5 \mathrm{~mm}$ sieve. Excess moisture was blotted from the cleaned roots by wrapping up the roots in layers of paper towel for 3 min (Schenk and Barber, 1979). For each pot three samples of $0.3 \mathrm{~g}$ fresh weight were used for the determination of root length by the line intersect method of Tannant (1975).

- Root length (Tennant, 1975)

Where:

$$
R L=\frac{11}{14} \times N \times G
$$

$\mathrm{RL}=$ root length, $\mathrm{N}=$ sum of horizontal and vertical crossing,

$\mathrm{G}=$ length of the grid unit $(2 \mathrm{~cm}$ or $1 \mathrm{~cm})$.

- Root Surface Area (Barber, 1995)

Surface area of a $1 \mathrm{~cm}$ root cylinder (SAC) was calculated as follows:

$$
S A C=2 \pi \times r_{0}
$$

Where $S A C=$ surface area of the root cylinder and $r_{0}=$ root radius

\section{- Root radius}

Estimation of root radius $\left(r_{0}\right)(\mathrm{cm})$ was based on the assumption that the specific weight of root is almost equal to that of water, $1 \mathrm{~g} \mathrm{~cm}^{-1}$ (Barber 1995).

$$
r_{0}=\sqrt{\frac{R F W}{\pi R L}}
$$

Where $\mathrm{RFW}=$ root fresh weight $(\mathrm{g})$ and $\mathrm{RL}=$ root length $(\mathrm{cm})$ and $r_{0}=$ root radius

\section{- Mean half distance between roots $\left(r_{1}\right)$}

Mean half distance between neighbouring roots ( $r 1$ ) was calculated according to (Schenk and Barber, 1979):

$$
r_{1}=\sqrt{\frac{V}{\pi R L}}
$$

Where $\mathrm{V}=$ volume of the soil in the pot $\left(\mathrm{cm}^{3}\right)$ and $\mathrm{RL}=$ root length per pot 


\section{Plant analyses}

Samples of shoots were measured from each pot and weighed, washed with running tap water and then with distilled water. The samples were air dried for few hours, and weight was measured, then oven dried at $65^{\circ} \mathrm{C}$ for 48 hours and grounded after recording the oven-dry weight of shoots. After dryness, the plant samples were ground by mill well and $0.5 \mathrm{~g}$ of oven-dried plant materials were digested with $\mathrm{H}_{2} \mathrm{SO}_{4}-\mathrm{H}_{2} \mathrm{O}_{2}$ digest (Lowther, 1980) and the digested solutions, were analysed for total nitrogen, phosphorus, potassium and cobalt. Total $\mathrm{N}$ was determined colorimetrically by Nessler method (Chapman and Pratt, 1961). The vanado molydate colorimetric method was used to measure $P$ in the digested plant samples (Jackson, 1967) using spectrophotometer at $480 \mathrm{~nm}$ wave length. Cobalt concentration was determined in the digested solution (Jackson, 1967) using the atomic absorption spectrophotometer (Model SpectrAA-200).

The obtained data were statistically analyzed according to the technique of analysis of variance (ANOVA) and the least significant difference (L.S.D) method was calculated to test the difference between the treatment means, as described by Gomez and Gomez (1984).

\section{RESULTS AND DISCUSSION}

\section{Barley and $\mathrm{E}$. Clover growth parameters}

\section{A. Shoot growth}

The results presented in Table (2) revealed that soaking barley and E. clover seeds in cobalt solutions and mycorrhizal inoculation had significant effects on shoot height, shoot fresh and dry weights and number of leaves.

Increasing cobalt concentration up to $0.6 \mathrm{mg} / \mathrm{l}$ in soaking solution for barley shoot growth parameters produced the highest plant length $(48.33 \mathrm{~cm})$, shoot fresh and dry weights (2.23 and $0.77 \mathrm{~g}$ ), and number of leaves/ plant (10.4). Conversely, increasing cobalt concentration up to $1.5 \mathrm{ppm}$ in soaking solution showed the lowest values $(45.5,6.92,1.38 \mathrm{~g}$ and $0.58 \mathrm{~g})$ for shoot height, number of leaves, shoot fresh and dry weights of barley, respectively. Cobalt promotes many developmental processes including stem and coleoptiles elongation, opening of hypocotyls hooks, leaf disc expansion and feet development (Ibrahim et. al., 1989). It is clear from Table (2) that there were highly significant positive interaction effects between cobalt concentrations and mycorrhizal species on shoot height, shoot fresh and dry weight of barley and E. Clover plants. 
J. Adv. Agric. Res. (Fac. Agric. Saba Basha)

Table (2). The main effects of cobalt concentrations and Mycorrhizae on shoot growth parameters of barley and E. Clover plants

\begin{tabular}{|c|c|c|c|c|c|c|c|c|}
\hline \multirow{2}{*}{ Treatments } & \multicolumn{2}{|c|}{$\begin{array}{l}\text { Shoot height } \\
\text { (cm/ plant) }\end{array}$} & \multicolumn{2}{|c|}{ No.of leaves/ plant } & \multicolumn{2}{|c|}{$\begin{array}{c}\text { Shoot fresh weight } \\
\text { (g/plant) }\end{array}$} & \multicolumn{2}{|c|}{$\begin{array}{c}\text { Shoot dry weight } \\
\text { (g/plant) }\end{array}$} \\
\hline & Barley & E. Clover & Barley & E. Clover & Barley & E. Clover & Barley & E. Clover \\
\hline \multicolumn{9}{|c|}{ Cobalt concentration, $\mathrm{mg} / \mathrm{l}(\mathrm{A})$} \\
\hline Control & 46.92d & $50.50 \mathrm{e}$ & $8.01 \mathrm{ab}$ & $55.55 \mathrm{~b}$ & $1.59 d$ & $2.11 \mathrm{c}$ & $0.63 d$ & $.514 d$ \\
\hline 0.3 & $47.56 c$ & $53.14 d$ & $9.04 \mathrm{~b}$ & $58.5 a b$ & $1.79 \mathrm{c}$ & $2.18 b c$ & $0.72 \mathrm{c}$ & $0.615 \mathrm{c}$ \\
\hline 0.6 & $48.33 a$ & $53.30 \mathrm{~cd}$ & $10.36 a$ & $59.23 a b$ & $2.23 a$ & $2.19 b c$ & $0.77 a$ & $0.618 \mathrm{c}$ \\
\hline 0.9 & $48.06 a b$ & 54. & & & & & & $34 \mathrm{~b}$ \\
\hline 1.2 & 47.6 & $54.78 \mathrm{a}$ & $9.32 \mathrm{ab}$ & & & & & \\
\hline 1.5 & $45.5 \mathrm{e}$ & $53.96 \mathrm{bc}$ & $6.92 \mathrm{~b}$ & $59.25 \mathrm{ab}$ & $1.38 \mathrm{e}$ & $2.26 \mathrm{~b}$ & $0.58 \mathrm{e}$ & $0.675 b$ \\
\hline \multicolumn{9}{|c|}{ Mycorrhizal inoculation (B) } \\
\hline Control & $\mathrm{C}$ & & & & $1.34 \mathrm{c}$ & 1.6 & $0.59 \mathrm{c}$ & $0.581 \mathrm{c}$ \\
\hline G.M & 47 & & & & & 2 & & $9 \mathrm{~b}$ \\
\hline G.I & $48.83 a$ & $54.66 \mathrm{a}$ & $11.8 \mathrm{a}$ & $66.51 a$ & $2.39 a$ & $2.92 a$ & $0.86 a$ & $0.689 a$ \\
\hline \multicolumn{9}{|c|}{ L.S.D 0.05} \\
\hline $\mathbf{A}$ & & & & 4.64 & 0.0 & & 0.1 & .008 \\
\hline B & 0.5 & & 2.41 & 6.56 & 0.0 & 0.144 & 0.03 & 0.012 \\
\hline AxB & 0.85 & 1.34 & ns & ns & 0.092 & 0.25 & 0.046 & 0.021 \\
\hline
\end{tabular}

*The values in each column followed by the same letter are not significant at 0.05 probability level

These results are in accordance with those obtained by Abd-Elgawad et al. (2014) and Gad and Abdel- Moez (2015). Previous studied have shown that cobalt also promotes the growth of seedlings and alleviates the senescence of aged tissues as it inhibits the activities of ACC oxidase and reduced ethylene production (Lau and Yang, 1976). On the other hand, increasing cobalt concentration for $\mathrm{E}$. Clover shoot growth parameters, in soaking solution up to $1.2 \mathrm{mg} / \mathrm{l}$, produced the highest shoot $(54.78 \mathrm{~cm})$; massive shoot fresh weight $(2.87 \mathrm{~g})$ and heaviest shoot dry weight $(0.713 \mathrm{~g})$. Also, this concentration showed the highest number of leaves/plant (62.19), but without significant difference with other concentrations (Atta-Aly et al., 1998). On the other hand, soaked E. Clover seeds in solution without cobalt gave the shortest shoot $(50.50 \mathrm{~cm})$, lowest number of leaves/plant (55.55) and lightest shoot dry weight $(0.514 \mathrm{~g})$. It is obvious that Co is an essential element for legumes because of its use by microorganisms in fixing atmospheric nitrogen (Evan and Kliwer, 1964). These results are in accordance with those obtained b Abdul Jaleel et al. (2009); and Gad and El-Metwally (2015).

Regarding mycorrhizal effect on barley and E. Clover shoot growth parameters, the results in Table (2) showed that treated barley and E. Clover seeds with mycorrhizae, significantly increased all the studied growth parameters as compared with the (control). It has been recognized that Arbuscular mycorrhizal (AM) fungi plays an essential role for nutrient uptake of the majority of plants, including many important crop species. The extraradical mycelium of the fungus takes up nutrients from the soil, transfers these nutrients to the intraradical mycelium within the host root, and exchanges the nutrients against carbon from the host across a specialized plant-fungal interface (Bücking and Kafle 2015). These 
results agreed with those reported by Bano and Ashfag (2013) and Abou Elseoud (2008). On the other hand, $G$. intraradiaces was more efficient than $G$. macrocarpium for the studied growth parameters of barley and $\mathrm{E}$. Clover plants. Similar results were reported by Banni and Faituri (2013) who reported that plants treated with $G$. intraradiaces had higher mycorrhizal colonization rate and was more effective than $G$. macrocarpium-treated plants.

\section{B. Root growth parameter}

The main treatment effects, including cobalt concentration in soaking solution and inoculated barley and $\mathrm{E}$. Clover seeds has exhibited significant trend on all root growth parameters, Table (3). The data also showed that treated barley seeds with $0.6 \mathrm{mg} / \mathrm{L}$ cobalt produced the heaviest root fresh and dry weights $(2.40$ and $0.52 \mathrm{~g})$, longest roots length $(1069.39 \mathrm{~cm})$ and highest root surface $\left(187.61 \mathrm{~cm}^{2}\right)$. Additional data revealed that soaking barley seeds in solutions contained the highest studied cobalt concentration $(1.5 \mathrm{mg} / \mathrm{L})$ showed maximum root radius $(0.028 \mathrm{~cm})$ and longest distance between roots $(0.572 \mathrm{~cm})$. These results are generally confirmed with those reported by Helmy and Gad (2002), and Gad and El-Metwally (2015). However, Atta-Aly et al. (1989) found that supplementing the nutrient solution with a concentration of $0.5 \mathrm{mg} / \mathrm{L} \mathrm{Co}^{2+}$ or less significantly induced ethylene production and adventitious root formation of tomato and squash cuttings. On the other hand, the results in Table (3) pointed out that the heaviest root fresh weight $(1.18 \mathrm{~g})$, dry weight $(0.61 \mathrm{~g})$, longest root length $(875.25 \mathrm{~cm})$ and highest root surface area $\left(113.06 \mathrm{~cm}^{2}\right)$ of $\mathrm{E}$. Clover plants was due to treatment by $1.2 \mathrm{mg} / \mathrm{L} \mathrm{Co}^{2+}$. Besides, the thickest root $(0.23 \mathrm{~cm})$ and widest distance between roots $(0.61 \mathrm{~cm})$ resulted from applied $0.6 \mathrm{mg} / \mathrm{L}$ cobalt and without cobalt application to soaking solution, respectively. However, soaking seeds of E. Clover seeds in solution without cobalt showed the lowest root fresh weight $(0.81)$ and dry weight $(0.184)$, shortest root $(619.30 \mathrm{~cm})$ and lowest root surface $\left(79.65 \mathrm{~cm}^{2}\right)$. Occonner (1992) showed that soybean grown without cobalt exhibited severe nitrogen deficiency, leading the death in about one of four plants. These results are in accordance with those obtained by Atta-Aly (2003). As shown in Table (3) there were highly significant positive interaction effect between cobalt concentration and mycorrhizal species on root fresh weight, root dry weight, root length, root radius and root surface for both two plants. 
Table (3). The main effect of cobalt concentrations and Mycorrhizae on root growth parameters of barley and E. Clover plants

\begin{tabular}{|c|c|c|c|c|c|c|c|c|c|c|c|c|}
\hline \multirow[t]{2}{*}{ Treatments } & \multicolumn{2}{|c|}{$\begin{array}{l}\text { Root fresh weight } \\
\text { (g/plant) }\end{array}$} & \multicolumn{2}{|c|}{$\begin{array}{c}\text { Root dry weight } \\
\text { (g/plant) }\end{array}$} & \multicolumn{2}{|c|}{$\begin{array}{l}\text { Root length } \\
\text { (cm/plant) }\end{array}$} & \multicolumn{2}{|c|}{$\begin{array}{l}\text { Root radius } \\
\text { (cm) }\end{array}$} & \multicolumn{2}{|c|}{$\begin{array}{l}\text { Mean half distance } \\
\text { between roots } \\
(\mathrm{cm})\end{array}$} & \multicolumn{2}{|c|}{$\begin{array}{l}\text { Root surface } \\
\left(\mathrm{cm}^{2} / \text { plant }\right)\end{array}$} \\
\hline & Barley & E.Clover & Barley & E.Clover & Barley & E.Clover & Barley & E.Clover & Barley & E.Clover & Barley & E.Clover \\
\hline \multicolumn{13}{|c|}{ Cobalt concentration, $\mathrm{mg} / \mathrm{l}(\mathrm{A})$} \\
\hline Control & $1.89 \mathrm{c}$ & $0.81 d$ & $0.42 \mathrm{c}$ & $0.18 d$ & $1004.29 b$ & $6.19 .30 \mathrm{e}$ & $0.0248 b$ & $0.02 b c$ & $0.497 \mathrm{~b}$ & $0.61 a$ & $153.67 \mathrm{c}$ & $79.65 \mathrm{e}$ \\
\hline 0.3 & $2.24 b$ & $1.01 \mathrm{c}$ & $0.43 c$ & $0.41 \mathrm{c}$ & $1011.97 b$ & $677.29 d$ & $0.0264 a b$ & $0.21 b$ & $0.491 b$ & $0.57 b$ & $168.38 \mathrm{bc}$ & $92.69 d$ \\
\hline 0.6 & $2.4 a$ & $1.04 b$ & $0.52 a$ & $0.42 c$ & $1069.39 a$ & $737.15 c$ & $0.0254 a b$ & $0.23 a$ & $0.4451 b$ & $0.55 c$ & $187.61 \mathrm{a}$ & $104.02 \mathrm{c}$ \\
\hline 0.9 & $2.3 b$ & $1.17 \mathrm{ab}$ & $0.51 a$ & $0.53 b$ & $1053.58 b$ & $851.45 a$ & $0.0265 a b$ & $0.02 b$ & $0.469 \mathrm{bc}$ & $0.51 \mathrm{de}$ & $174.85 \mathrm{ab}$ & $109.35 \mathrm{ab}$ \\
\hline 1.2 & $2.3 b$ & $1.18 a$ & $0.46 \mathrm{~b}$ & $0.61 \mathrm{a}$ & $1042.67 b$ & $875.25 a$ & $0.0260 \mathrm{ab}$ & $0.019 \mathrm{c}$ & $0.472 \mathrm{bc}$ & $0.51 \mathrm{e}$ & $170.89 a b c$ & $113.06 a$ \\
\hline 1.5 & $1.66 \mathrm{~d}$ & $1.16 a b$ & $0.38 d$ & $0.52 b$ & $739.4 \mathrm{c}$ & $808.05 b$ & $0.0275 a$ & $0.029 b$ & $0.572 a$ & $0.53 d$ & $122.96 d$ & $107.67 \mathrm{bc}$ \\
\hline \multicolumn{13}{|c|}{ Mycorrhizal inoculation (B) } \\
\hline Control & $1.7 \mathrm{c}$ & $0.95 c$ & $0.37 c$ & $0.196 c$ & $775.35 c$ & $685.47 c$ & $0.0268 a$ & $0.020 \mathrm{~b}$ & $0.554 a$ & $0.58 a$ & $127.88 \mathrm{c}$ & $92.73 c$ \\
\hline G.M & $1.83 \mathrm{~b}$ & $1.07 \mathrm{~b}$ & $0.42 b$ & $0.528 \mathrm{~b}$ & $938.63 b$ & $759.12 b$ & $0.0251 a$ & $0.021 a b$ & $0.499 b$ & $0.55 b$ & $146.38 b$ & $101.09 b$ \\
\hline G.I & $2.87 a$ & $1.21 \mathrm{a}$ & $0.57 a$ & $0.623 a$ & $1296.68 a$ & $839.66 a$ & $0.0264 a$ & $0.021 a$ & $0.422 \mathrm{c}$ & $0.52 \mathrm{c}$ & $214.91 a$ & $109.4 a$ \\
\hline \multicolumn{13}{|c|}{ L.S.D 0.05} \\
\hline A & 0.07 & 0.03 & 0.02 & 0.019 & 98.4 & 36.67 & 0.003 & 8.55 & 0.035 & 0.01 & 18.82 & 3.79 \\
\hline B & 0.05 & 0.02 & 0.01 & 0.013 & 69.61 & 25.93 & 0.002 & 6.04 & 0.025 & 0.01 & 13.3 & 2.68 \\
\hline AxB & 0.12 & 0.06 & 0.013 & 0.033 & 170.52 & 63.5 & 0.004 & 0.001 & ns & 0.026 & 32.58 & 6.57 \\
\hline
\end{tabular}

${ }^{*}$ The values in each column followed by the same letter are not significant at 0.05 probability level 
As shown in Table (3), inoculated seeds barley and E. Clover with mycorrhizae generally increased significantly all the studied root parameters except root radius and mean half distance between roots compared to the other plants without mycorrhizal inoculation (control). Inoculation barley and E. Clover with $G$. intraradiaces (G.I) produced the heaviest root fresh and dry weights $(2.87$ and $0.57 \mathrm{~g})$, tallest root length $(1296.68 \mathrm{~cm})$ and largest root surface $\left(214.91 \mathrm{~cm}^{2}\right)$ compared with the other mycorrhizal species ( $G$. macrocarpium). Abou Elseoud (2005) and Puttaradder and Lakshman (2015) reported similar results. They found that mycorrhizal inoculation greatly influenced plant growth, root length, fresh and dry weight of shoots and roots. Also, Abou Elseoud (2008) showed that plants inoculation by mycorrhizal fungi significantly increased root length and root surface area compared to the control.

\section{Barley and E. Clover macronutrients content}

Considering cobalt concentrations and mycorrhizal inoculation effects on nitrogen, phosphorus and potassium contents and uptake by barley and $\mathrm{E}$. Clover plants, results presented in Table (4) revealed that both studied factors had significant effects on the studied traits. With respect to cobalt concentrations in soaking solutions of barley plants, results showed that low concentration level $(0.6 \mathrm{mg} / \mathrm{L})$ produced the highest $\mathrm{N}, \mathrm{P}$ and $\mathrm{K}$ plant contents $(18.17,10.05$ and $45.43 \mathrm{mg} / \mathrm{g}$ d.m.) and uptake (16.9, 8.43 and $19.81 \mathrm{mg} /$ plant), respectively. Conversely, the highest cobalt concentration $(1.5 \mathrm{mg} / \mathrm{L})$ showed the lowest $\mathrm{N}, \mathrm{P}$ and $\mathrm{K}$ contents in barley plant $(9.38,3.85$ and $32.65 \mathrm{mg} / \mathrm{g} \mathrm{d.m}$ ) and uptake (4.35, 2.07 and 18.3mg/ plant), respectively. Gad and Azize (2011) and Atiia et al. (2016) reported similar results. On the other hand, results in Table (4) pointed out that applied $1.2 \mathrm{mg}$ cobalt $/ \mathrm{L}$ to soaking solution produced the highest $\mathrm{N}, \mathrm{P}$ and $\mathrm{K}$ content in $\mathrm{E}$. clover plants $(24.89,11.75$ and $28.96 \mathrm{mg} / \mathrm{g} \mathrm{d.m}$.) and uptake $(16.9,8.43$ and $19.81 \mathrm{mg} /$ plant), respectively. However, the lowest values due to soaking solution without cobalt the (control). Cobalt had positive effect due to several induced effects in hormonal synthesis (auxin and gibberellin contents) and metabolic activity resulted in maximum growth and yield of tomato, and increase the activity of some enzymes i.e. peroxidase and catalase in plant and hence increasing the catabolism rather than anabolism (Gad, 2005). As shown in Table (4) there were highly significant interaction effect between cobalt concentrations and mycorrhizal species on $\mathrm{N}, \mathrm{P}$, and $\mathrm{K}$ content and uptake of both two plants. 
Table (4). The main effects of cobalt concentrations and Mycorrhizae on N, P and K content and uptake of barley and E. Clover plants

\begin{tabular}{|c|c|c|c|c|c|c|c|c|c|c|c|c|}
\hline \multirow[t]{2}{*}{ Treatments } & \multicolumn{2}{|c|}{$\begin{array}{l}\text { N content } \\
\text { (g/kg d.m) }\end{array}$} & \multicolumn{2}{|c|}{$\begin{array}{c}\text { P content } \\
\text { (mg/g d.m) }\end{array}$} & \multicolumn{2}{|c|}{$\begin{array}{c}\text { K content } \\
\text { (mg/g d.m) }\end{array}$} & \multicolumn{2}{|c|}{$\begin{array}{c}\text { N uptake } \\
\text { (mg/plant) }\end{array}$} & \multicolumn{2}{|c|}{$\begin{array}{c}\text { P uptake } \\
\text { (mg/plant) }\end{array}$} & \multicolumn{2}{|c|}{$\begin{array}{c}\text { K uptake } \\
\text { (mg/plant) }\end{array}$} \\
\hline & Barley & E.Clover & Barley & E.Clover & Barley & E.Clover & Barley & E.Clover & Barley & E.Clover & Barley & E.Clover \\
\hline \multicolumn{13}{|c|}{ Cobalt concentration, mg/l (A) } \\
\hline Control & $10.4 \mathrm{e}$ & $15.95 d$ & $4.94 d$ & $2.53 \mathrm{e}$ & $34.39 d$ & $23.16 \mathrm{~d}$ & $5.18 \mathrm{e}$ & $5.70 d$ & $3.0 \mathrm{e}$ & $1.10 \mathrm{~d}$ & $19.85 \mathrm{e}$ & $9.59 d$ \\
\hline 0.3 & $11.99 d$ & $19.24 c$ & $5.23 d$ & $4.02 d$ & $35.25 d$ & $24.35 \mathrm{~cd}$ & $7.23 d$ & $9.93 c$ & $3.61 d$ & $2.26 \mathrm{~cd}$ & $21.49 d$ & $13.49 c$ \\
\hline 0.6 & $18.17 a$ & $21.86 b$ & $10.05 a$ & $4.82 \mathrm{~cd}$ & $45.43 a$ & $24.81 c$ & $13.51 \mathrm{a}$ & $11.64 \mathrm{c}$ & $8.13 a$ & $2.84 c$ & $33.09 a$ & $14.10 \mathrm{c}$ \\
\hline 0.9 & $14.83 b$ & $23.96 a$ & $7.88 \mathrm{~b}$ & $6.46 \mathrm{~b}$ & $42.64 b$ & $27.55 b$ & $10.3 b$ & $15.07 a b$ & $6.17 \mathrm{~b}$ & $4.39 b$ & $30.26 b$ & $17.95 b$ \\
\hline 1.2 & $13.55 c$ & $24.89 a$ & $6.45 c$ & $11.75 a$ & $39.42 c$ & $28.96 a$ & $9.3 \mathrm{c}$ & $16.9 a$ & $4.42 \mathrm{c}$ & $8.43 a$ & $27.67 c$ & 19.81a \\
\hline 1.5 & $9.38 f$ & $22.57 b$ & $3.85 \mathrm{e}$ & $5.49 c$ & $32.65 \mathrm{e}$ & $26.55 b$ & $4.35 f$ & $13.69 b$ & $2.07 f$ & $3.57 \mathrm{bc}$ & 18.30f & $16.77 b$ \\
\hline \multicolumn{13}{|c|}{ Mycorrhizal inoculation (B) } \\
\hline Control & $8.03 c$ & $17.97 \mathrm{c}$ & $2.76 \mathrm{c}$ & $3.30 \mathrm{c}$ & $30.83 c$ & $23.46 c$ & $3.57 \mathrm{c}$ & $6.83 \mathrm{c}$ & $1.45 \mathrm{c}$ & $1.54 \mathrm{c}$ & $16.91 \mathrm{c}$ & $10.83 c$ \\
\hline G.M & $11.34 b$ & $21.66 b$ & $5.17 \mathrm{~b}$ & $5.89 \mathrm{~b}$ & $35.92 b$ & $25.54 b$ & $5.87 \mathrm{~b}$ & $13.01 \mathrm{~b}$ & $3.0 \mathrm{~b}$ & $3.77 b$ & $20.95 b$ & $15.63 b$ \\
\hline G.I & $19.60 \mathrm{a}$ & 24.61 & $11.27 a$ & $8.36 a$ & $48.15 a$ & $28.68 a$ & $15.48 \mathrm{a}$ & $16.63 a$ & $9.24 a$ & $5.99 a$ & $37.68 \mathrm{a}$ & $19.41 \mathrm{a}$ \\
\hline \multicolumn{13}{|c|}{ LSD $_{.05}$} \\
\hline $\mathbf{A}$ & 0.57 & 1.31 & 0.36 & 0.94 & 1.34 & 1.32 & 0.39 & 1.91 & 0.22 & 1.40 & 1.21 & 1.32 \\
\hline B & 0.4 & 0.92 & 0.26 & 0.66 & 0.95 & 0.94 & 0.28 & 1.35 & 0.15 & 0.99 & 0.85 & 0.94 \\
\hline AxB & 0.98 & 2.27 & 0.062 & 1.63 & 2.33 & 2.30 & 0.68 & 3.31 & 0.37 & 2.42 & 2.08 & 2.30 \\
\hline
\end{tabular}

${ }^{*}$ The values in each column followed by the same letter are not significant at 0.05 probability level 
Results presented in Table (4) showed that uninoculated barley and E. Clover seeds with mycorrhizae showed the lowest N, P, and K plant content and uptake respectively. However, inoculated seeds with G.intraradiaces showed a significant highest N, P and K content and uptake compared to the other plants inoculated with $G$. macrocarpium. Mycorrhizal plants roots hyphae can increase the branching of root system in rhizosphere so that mycorrhizal plants roots have more absorption efficiency compared to non-mycorrhizal ones. These results are in agreement with those found by Nourinia et al. (2007) and Robinson et al. (2014).

\section{Cobalt contents in barley and E. Clover plants}

Table (5) indicated that cobalt contents in shoot, root and whole barley and E. Clover plants were significantly affected by cobalt concentrations in soaking solution and mycorrhizal inoculation.

The results, showed that, applied $1.5 \mathrm{mg} / \mathrm{L}$ cobalt to soaking solution produced the highest amount of available cobalt in soil $(0.17$ and $0.21 \mathrm{mg} / \mathrm{kg}$ soil); and in total shoot cobalt contents (4.99 and $1.81 \mathrm{mg} / \mathrm{g} \mathrm{d.m})$; root cobalt contents $(7.51$ and 17.81 $\mathrm{mg} / \mathrm{g} \mathrm{d} . \mathrm{m})$ and total plant cobalt contents (12.51 and $19.62 \mathrm{mg} / \mathrm{g} \mathrm{d} . \mathrm{m})$ for barley and $\mathrm{E}$. Clover plants, respectively.

Conversely, the control treatment produced the lowest cobalt in shoot, root and plant content. Similarly, Gad and Abdel-Moez (2015) reported that cobalt content in fenugreek grains significantly increased with increasing cobalt concentration in plant growing in media as compared to the control.

Concerning mycorrhizal effect, results presented in Table (5) revealed that inoculation both barley seeds and $\mathrm{E}$. Clover seeds with $\mathrm{G}$. intraradiaces showed the highest amount of available cobalt $(0.17$ and $0.25 \mathrm{mg} / \mathrm{kg}$ soil); shoot cobalt contents (3.88 and $2.03 \mathrm{mg} / \mathrm{g} \mathrm{d} . \mathrm{m})$, root cobalt contents $(7.16$ and $14.99 \mathrm{mg} / \mathrm{g} \mathrm{d} . \mathrm{m}$ ) and total plant cobalt contents $(11.05$ and $17.01 \mathrm{mg} / \mathrm{g} \mathrm{d} . \mathrm{m}$.) for the two plants, respectively as compared to the other mycorrhizal species ( $G$. macrocarpium).

However, the lowest cobalt content resulted from unicoculated seeds. It can be seen from Table (5) that there were highly significant positive interaction effect between cobalt concentrations and mycorrhizal species on available $\mathrm{Co}^{2+}$ in soil, shoot $\mathrm{Co}^{2+}$, root $\mathrm{Co}^{2+}$ and plant cobalt content for both barley and E. Clover plants. 
Table (5). The main effects of cobalt concentrations and Mycorrhizae on available cobalt in soil and cobalt content of barley and E. Clover plants

\begin{tabular}{|c|c|c|c|c|c|c|c|c|}
\hline \multirow[t]{2}{*}{ Treatments } & \multicolumn{2}{|c|}{$\begin{array}{c}\text { Available } \mathrm{Co}^{2+} \\
\text { (mg/ kg soil) }\end{array}$} & \multicolumn{2}{|c|}{$\begin{array}{l}\text { Shoot } \mathrm{Co}^{2+} \text { content } \\
(\mathrm{mg} / \mathrm{kg} \text { d.m })\end{array}$} & \multicolumn{2}{|c|}{$\begin{array}{l}\text { Root } \mathrm{Co}^{2+} \text { content } \\
(\mathrm{mg} / \mathrm{kg} \text { d.m })\end{array}$} & \multicolumn{2}{|c|}{$\begin{array}{l}\text { Plant } \mathrm{Co}^{+2} \text { content } \\
(\mathrm{mg} / \mathrm{kg} \text { d.m })\end{array}$} \\
\hline & Barley & E.Clover & Barley & E.Clover & Barley & E.Clover & Barley & E.Clover \\
\hline \multicolumn{9}{|c|}{ Cobalt concentration, $\mathrm{mg} / \mathrm{l}(\mathrm{A})$} \\
\hline Control & $0.135 c$ & $0.02 \mathrm{e}$ & $0.22 \mathrm{e}$ & $0.11 \mathrm{~d}$ & $0.43 d$ & $0.74 \mathrm{e}$ & $0.65 d$ & $0.85 \mathrm{e}$ \\
\hline 0.3 & $0.15 b c$ & $0.02 \mathrm{e}$ & $0.23 d$ & $0.14 \mathrm{c}$ & $0.45 \mathrm{~cd}$ & $0.93 d$ & $0.68 d$ & $1.07 \mathrm{~d}$ \\
\hline 0.6 & $0.15 a b c$ & $0.03 d$ & $0.25 \mathrm{c}$ & $0.16 \mathrm{~b}$ & $0.51 \mathrm{bc}$ & $1.11 \mathrm{c}$ & $0.76 \mathrm{c}$ & $1.28 \mathrm{c}$ \\
\hline 0.9 & $0.16 \mathrm{ab}$ & $0.11 \mathrm{c}$ & $0.25 \mathrm{c}$ & $0.17 a b$ & $0.55 b$ & $1.23 \mathrm{~b}$ & $0.81 \mathrm{bc}$ & $1.40 \mathrm{~b}$ \\
\hline 1.2 & $0.16 \mathrm{ab}$ & $0.18 \mathrm{~b}$ & $0.31 \mathrm{~b}$ & $0.17 a b$ & $0.56 \mathrm{~b}$ & $1.27 \mathrm{~b}$ & $0.88 \mathrm{~b}$ & $144 \mathrm{~b}$ \\
\hline 1.5 & $0.17 a$ & $0.21 \mathrm{a}$ & $0.49 a$ & $0.18 \mathrm{a}$ & $0.75 a$ & $1.78 \mathrm{a}$ & $1.25 \mathrm{a}$ & $1.96 \mathrm{a}$ \\
\hline \multicolumn{9}{|c|}{ Mycorrhizal inoculation (B) } \\
\hline Control & $0.13 \mathrm{c}$ & $0.01 \mathrm{c}$ & $0.20 \mathrm{c}$ & $0.09 \mathrm{c}$ & $0.37 \mathrm{c}$ & $0.93 \mathrm{c}$ & $0.57 \mathrm{c}$ & $1.02 \mathrm{c}$ \\
\hline G.M & $0.15 b$ & $0.03 b$ & $0.29 b$ & $0.17 \mathrm{~b}$ & $0.55 \mathrm{~b}$ & $1.11 \mathrm{~b}$ & $0.84 \mathrm{~b}$ & $1.29 \mathrm{~b}$ \\
\hline G.I & $0.17 \mathrm{a}$ & $0.25 \mathrm{a}$ & $0.38 \mathrm{a}$ & $0.20 \mathrm{a}$ & $0.71 \mathrm{a}$ & $1.49 \mathrm{a}$ & $1.11 \mathrm{a}$ & $1.70 \mathrm{a}$ \\
\hline \multicolumn{9}{|c|}{ LSD $_{.05}$} \\
\hline $\mathbf{A}$ & 0.01 & 0.006 & 0.009 & 0.01 & 0.07 & 0.045 & 0.075 & 0.04 \\
\hline B & 0.015 & 0.004 & 0.006 & 0.009 & 0.05 & 0.031 & 0.053 & 0.03 \\
\hline AxB & 0.025 & 0.009 & 0.016 & 0.023 & 0.12 & 0.078 & 0.13 & 0.08 \\
\hline
\end{tabular}

${ }^{*}$ The values in each column followed by the same letter are not significant at 0.05 probability level

\section{CONCLUSION}

It can be concluded that soaking seeds of barley and E. Clover in cobalt solution and mycorrhizal inoculation had significant effects on all growth parameters of the two plants. Moreover, the interaction was highly positive between cobalt concentrations and mycorrhizae species with both crops forge. Under the same experimental conditions, it can be recommended that $G$. intraradiaces was more effective than $G$. macrocarpium for the studied traits. Also, the recommended cobalt concentration for barley crops was lower $(0.6 \mathrm{mg} / \mathrm{l})$ than that for $\mathrm{E}$. Clover $(1.2 \mathrm{mg} / \mathrm{l})$ since legume plants needs cobalt supply for enhancing nitrogen fixation in all Rhizobium species and hence promotes legume growth.

\section{REFERENCES}

Abd-Elgawad, M. M. M., Nadia Gad and M. M. A. Hammam, (2014).Canola Plant Media in Relation to Growth, Seed Yield, Oil Content, and Phytonematodes. Middle East. J. Agric. Res, 3(4): 907-911.

Abdul Jaleel, C., K. Jayakumar, Z. Chang-Xing and M. Iqbal (2009). Low concentration of cobalt increases growth, biochemical constituents, mineral status and yield in Zea mays. J. Sci. Res, 1: 128-137.

Abou El Seoud, I.I.A. (2008). Phosphorus Efficiency of Tagetes Plant Inoculated with Two Arbuscular Mycorrhizal Fungi Strains. Aust. J.Basic \& Appl. Sci., 2(2): 234242.

Abou El Seoud, I.I.A. (2005). Influence of mycorrhizae and phosphate mobilizing bacteria on $P$ nutrition of some vegetable crops. Ph.D thesis, Faculty of Agriculture (Saba Basha), Alexandria University, Egypt, pp: 126. 
Amri, A., L. Ouammou and F. Nassif (2005). Barley-based food in Southern Morocco. In S. Grando \& H. Gomez Macpherson (Eds.), Food barley: Importance, uses and local knowledge (pp.22-28). Syria: ICARDA.

Atiia, M. A., M.A. Abd Alla and S.M.M. Allam (2016). Effect of zinc and cobalt applied with different methods and rates on the yield components of Vicia Faba L. World Wide Journal of Multidisciplinary Research and Development, 2(2): 52-582.

Atta-Aly, M. A. (1998). Soaking summer squash seeds in low concentration of cobalt solution before sowing increasing plant growth, femaleness, and fruit yield via increasing plant ethylene level. J. Plant Growth Regul, 17: 25-32.

Atta-Aly, M. A. (2003). Effect of galia melon seed soaking in cobalt solution on plant growth, fruit yield, quality and sudden wilt disease infection. Agric. Investment Magazine, 1: 67-72.

Atta-Aly, M.A., N. G Shehata and T.M Kobbia (1989). Effect of ethylene inhibitors, ethrel, and auxins on the formation, growth, and development of adventitious root in tomato and squash cuttings. Egypt. J. Hort, 16: 45-57.

Banni, A. S. and M.Y. Faituri (2013). The role of arbuscular mycorrhizae Glomus Spp (mixed) and Glomus fasciculatum in growth and copper uptake of maize grown in soil contaminated with copper. Middle-East J. Sci. Res, 17 (1): 77-83.

Bano, S A. and D. Ashfaq (2013). Role of mycorrhiza to reduce heavy metal stress. Nat. Sci, 5 (12A): 16-20.

Barber, S. A. (1995). Soil nutrient bioavailability: A Mechanistic Approach. John Wiley \& Sons. Inc. pp. 157-179.

Black, C.A., ed (1965). Methods of soil analysis. Part 1 and Part 2. Am. Soc. Agron. No 9, Madison, Wisconsin. USA.

Bothe, H., K. Turnau and M. Regvar (2010). The potential role of arbuscular mycorrhizal fungi in protecting endangered plants and habitats. Mycorrhiza, 20(7): 445-457.

Bücking, H. and A. Kafle (2015). Role of Arbuscular Mycorrhizal Fungi in the Nitrogen Uptake of Plants: Current Knowledge and Research Gaps. Agronomy, 5: 587612.

Ceccarelli, S., S. Grando and J. A. G. van Leur (1987). Genetic diversity in barley landraces from Syria and Jordan. Euphytica, 36: 389-405.

Chapman, H. D. and P. F. Pratt (1961). Methods of analysis for soils, plant and water .Univ. Calif., Dept. Agric. Sci, USA.

El-Bably, A.Z. (2002). Effect of irrigation and nutrition of copper and molybdenum on Egyptian clover (Trifolium alexandrinum L.). Agron. J, 94: 1066-1070.

Evan, H. J. and M. Kliwer (1964). Vitamin B compounds in relation to the requirements of cobalt for higher plants and nitrogen fixing organisms. Ann. New York Acad. Sci, 2: 732-755.

Gad, N. (2005). Effect of cobalt on tomato growth, yield and fruit quality. Egypt. J. Agric. Sci, 20: 260.

Gad, N. and E. E. Aziz (2011). Physiological and Chemical Response of Lemongrass (Cymbopogon Citratus L.) to Cobalt Nutrition, B-Endogenous hormones, chemical and nutrional contents. J. Appl. Sci. Research, 7(12): 1778-1784. 
Gad, N and I.M. El-Metwally (2015). Chemical and physiological response of maize to salinity using cobalt supplement. Int. J. Chem. Tech. Res, 8(10): 45-52.

Gad, N. and M. R. Abdel-Moez (2015). Effect of cobalt on growth and yield of fenugreek plants. Int. J. Chem. Tech, 8 (11): 85-92.

Gad, N., M.R. Abdel-Moez and H. Kandil (2012). Influence of Cobalt and Mycorrhizae Mediated Phosphorus on Some Higher Plants Growth and Yield. J. Basic. Appl. Sci. Res, 2(11): 11942-11951.

Gomez, K.A. and A.A. Gomez (1984). Statistical Procedures for Agricultural Research. 2nd Edition, John Wiley and Sons, New York.

Helmy, L. M. and N. Gad (2002). Effect of cobalt fertilization on the yield, quality and essential oil composition of parsely leaves. Arab Univ. J. of Agric. Sci., Ain Shams Univ. Cairo, Egypt, 10(3): 779-802.

Ibrahim, A., S. El-Abd and A.S. El-Beltagy (1989). A possible role of cobalt in salt tolerance of plant. Egypt. J. Soil Sci, Special Issue, pp: 359-371.

Jackson, M. L. (1967). Soil Chemical Analysis. Prentice Hall of India Pvt. Ltd, New Delhi.

Jakson, M. L (1973). Soil Chemical Analysis. Constable Co. Ltd, London.

Lau, O.L. and S. F. Yang (1976). Stimulation of ethylene production in the mung bean hypocotyls by cupric ion, calcium ion, and kinetin. Plant Physiol, 57(1): 88-92.

Lindsay, W. L. and W. A. Norvell (1978). Development of DTPA soil test for Zn, Fe, $\mathrm{Mn}$, and Cu. Soil Sci. Soc Am. J, 42: 421-427.

Lowther, J. R (1980). Use of single sulfuric acid-hydrogen peroxide. Digest for the analysis of Pinus radiata needles. Comm. Soil Sci. Plant Annal, 11: 175-188.

Murphy $\mathbf{J}$ and J. P. Riley (1962). A modified single solution method for the determination of phosphate in natural waters. Analytica Chimica Acta, 27: 31-36. 12.

Nouriana, A. A., E. Faghani, F. Rejali, A.Safarnezhad, A. and M. R. Abbasi (2007). Evaluation effect of symbiosis of mycorrhiza on 74-yield components and some physiological parameters of barley genotypes under salinity stress. Asian Plant Sciences Journal, 6: 1108-1112.

Occonner, M.B (1992). Role of cobalt in soil and plant nutrition. New Zealand J. Agric. Sci. (Wellington), 18: 119-122.

Palit, S., A. Sharma and G. Talukder (1994). Effects of cobalt on plants. Bot. Rev, 60:149-181.

Puttaradder, J. and H.C. Lakshman (2015). Screening of efficient AM fungus for Brassica juncea (L.) Czern and Coss to improve biomass yield and seeds number. Int. J. Pure App. Biosci, 3 (3): 147-152.

Riley, I.T. and M. J. Dilwarth (1985). Cobalt status and its effects on soil populations of rhizobium lupine, rhizosphere colonization and nodule initation-Soil biology and Biochemistry, 17: 81-85.

Robinson, J. P., K. Nithya, R. Ramya, B. Karthikbalan and K. Kripa (2014). Effect of Vesicular Arbuscular Mycorrhiza Glomus fasiculatum on the growth and Physiological response in Sesamum indicum L. International Letters of Natural Sciences, 23: 47-62. 
Schenk, M. K. and S. A. Barber (1979). Phosphate uptake by corn as affected by soil characteristics and root morphology. Soil. Sci. Soc Am. J, 43: 880-883.

Tannant, D (1975). A test of a modified line intersect method of estimating root length. J. Ecol, 63: 995-1001.

Walser, R.H., V.D. Jolley and T.D. Davis (1996). Effect of cobalt application on structural organization of photosynthetic apparatus of tomato leaves. Plant Nutr, 19:358-368.

$$
\text { الملخص العربي }
$$

تأثير إضافة الكويالت والتلقيح بفطر الميكورايزا على نمو ومحتوى بعض العناصر الغذائية

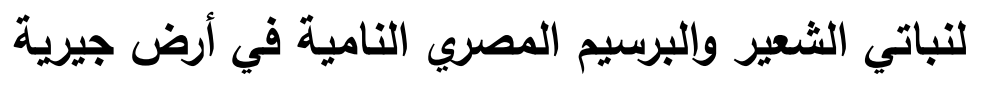

$$
\begin{aligned}
& \text { مصطفى المهذي مفتاح' ، اسلام ابراهيم ابو السعود '، ماهر جورجي نسيم؟ }
\end{aligned}
$$

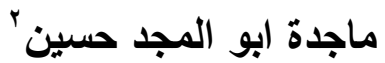

$$
\begin{aligned}
& \text { 'قسم التربة والمياه ،كلية الزراعة ، جامعة بني وليد- للييا }
\end{aligned}
$$

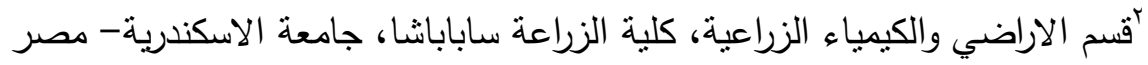

اجريت هذه الدراسة في الصوبة الزجاجية بكلية الزراعة ساباباشا جامعة الاسكندرية لدراسة تاثير اضافة الكوبالت بنقع البذور

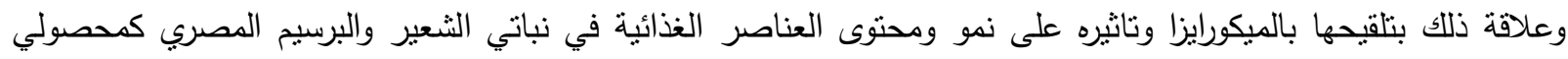

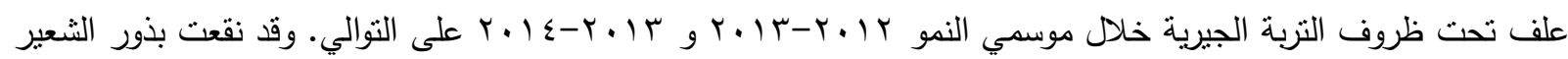

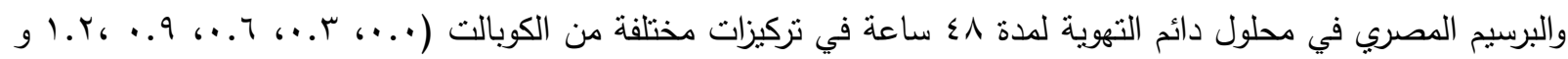

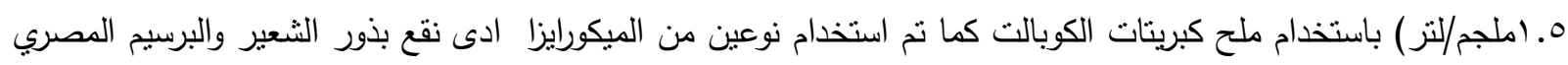

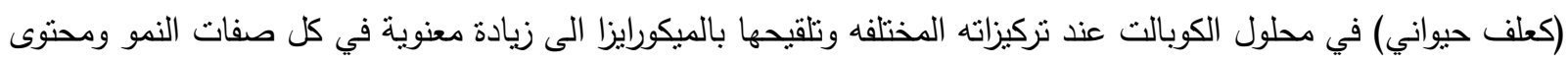
العناصر الغذائية المختبرة في المجموع الخضري والجذري. أدت اضافة الكوبالت الى زيادة محنوى

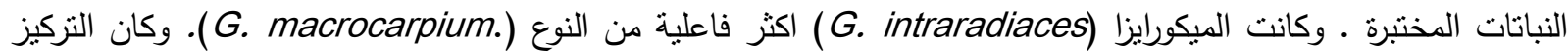

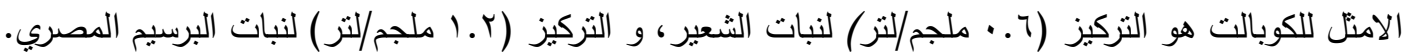


